\title{
Total Aortic Occlusion: A Rare Cause of Paraplegia
}

\author{
(D) Emine Munise Baysal, (D) Mücahit Şentürk, (D) Mehmet Esat Ferhatlar, (D) Asım Kalkan \\ University of Health Sciences Turkey, Prof. Dr. Cemil Taşçıŏlu City Hospital, Clinic of Clinic of Emergency Medicine, Istanbul, Turkey
}

\section{Abstract}

Total aortic occlusion is a rare disease and may lead to catastrophic outcomes. Although it can be acute or subacute, mortality or morbidity is high if early intervention is not performed. In this report, we described the case of a 90-year-old female patient with total aortic occlusion who presented to the emergency department with paraplegia.

Keywords: Aortic occlusion, paraplegia, totally

\section{INTRODUCTION}

A 90-year-old female patient presented to our emergency department with a sudden onset of inability to walk, leg numbness, and back pain. She has no history other than ischemic heart disease. On admission, she had blood pressure of 200/90 $\mathrm{mmHg}$, pulse rate of 86 beats per minute, and respiration rate of 16 breaths per minute. On physical examination, peripheral pulses could not be obtained; bilateral lower extremities were pale and cold; and she had muscle strength of $1 / 5$. Aortoperipheral contrast-enhanced computed tomography (CT) angiography showed total aortic occlusion in the infrarenal region, including the iliac arteries.

Informed consent was obtained from the patient for the publication of this case report.

\section{Total Aortic Occlusion}

Total aortic occlusion is a rare disease and may lead to catastrophic outcomes. Although it can be acute or subacute, mortality or morbidity is high if early intervention is not performed. "Leriche syndrome" is defined as total aortic occlusion presented to the emergency department with the absence of lower extremity pulse, erectile dysfunction, and loss of sensation (1). The gold standard for diagnosis is contrast-enhanced CT angiography. Our patient was admitted to the emergency department with low back pain and inability to walk. Pulse examination prevented misdiagnosis. Tissue hypoxia was the cause of the low back pain and leg pain. The main reason for the inability to walk is the occlusion of the vertebral arteries (2). In particular, patients presenting with low back pain can often be overlooked in the emergency department. Therefore, for aortic occlusion, appropriate and careful examination of patients with low back pain and paraplegia is important.

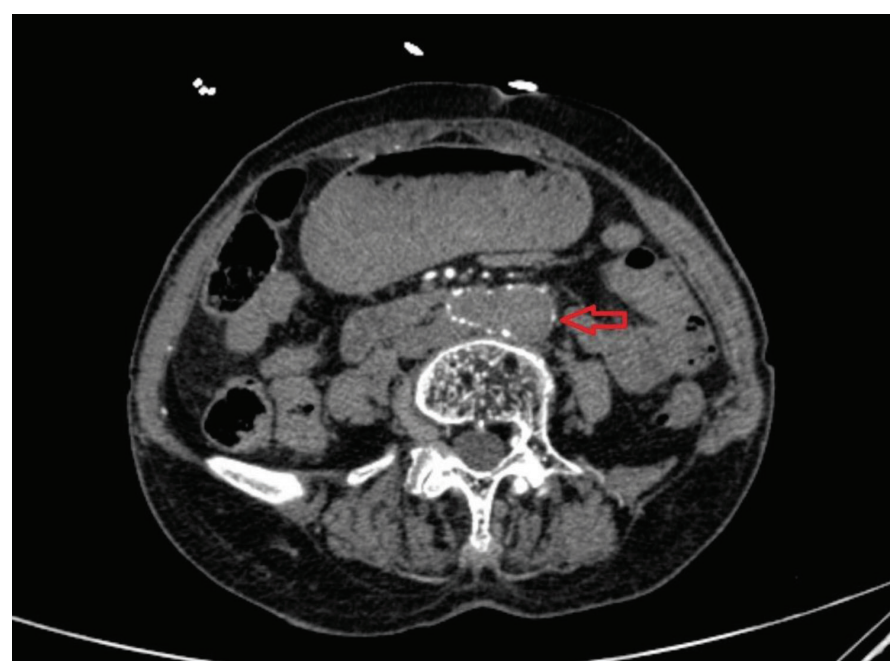

Figure 1. Total aortic occlusion at the infrarenal level (transverse) 


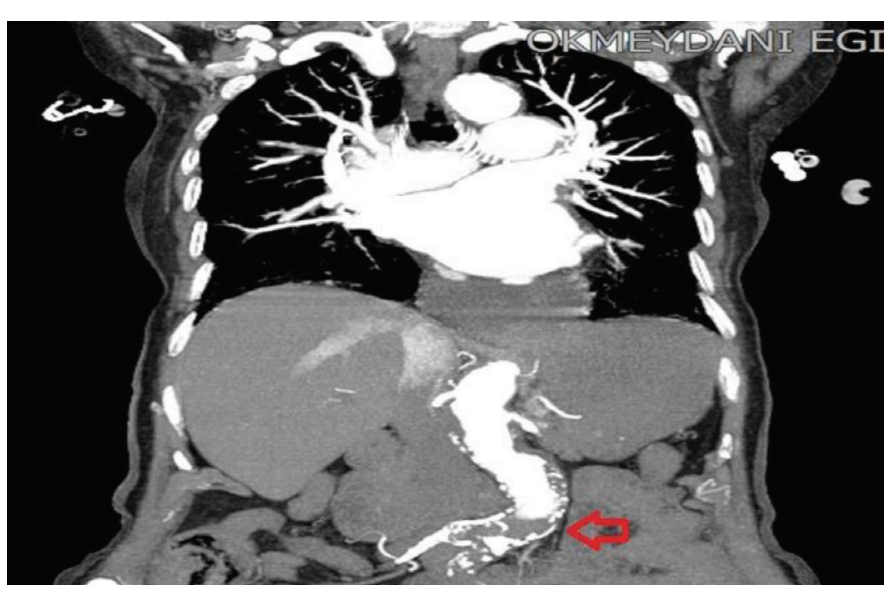

Figure 2. Total aortic occlusion at the infrarenal level (sagittal)

\section{Ethics}

Informed Consent: Informed consent was obtained from the patient for the publication of this case report.
Peer-review: Externally and internally peer-reviewed.

\section{Authorship Contributions}

Concept: A.K., E.M.B., Design: M.S., Data Collection or Processing: E.M.B., M.S., Analysis or Interpretation: A.K., M.E.F., E.M.B., Literature Search: E.M.B., M.E.F., M.Ş., Writing: A.K., M.Ş., M.E.F.

Conflict of Interest: No conflict of interest was declared by the authors.

Financial Disclosure: The authors declared that this study received no financial support.

\section{REFERENCES}

1. Mahendrakar SM, Sandhu HS, Khan AH, Loya YS. Leriche syndrome: acute onset painful paraplegia of vascular origin with catastrophic consequences. J Clin Diagn Res 2017;11:22-3.

2. Dutu B, Zdrenghea D, Pop D, Cismaru G, Martis A, Iancu AC. Symptomatic total aortic occlusion. Am J Case Rep 2018;19:589-92. 